\title{
Marital Relation Strategies for Businessman: Husband vs. Wife Perspective
}

\author{
Ersa Lanang Sanjaya and Jimmy Ellya Kurniawan
}

\begin{abstract}
The previous study showed that marital relation strategies, based on the husband perspective, could increase the husband efficacy to running and develop his business through spousal involvement and emotional social support. That last study didn't investigate yet about the similarity between the husband's marital relation strategy attitude and the wife expectation about the strategies. The purpose of this study is investigating the similarity of marital relation strategies between the husband attitude and the wife expectation. The subjects were 14 businessmen and his spouse in Surabaya, Indonesia. All of data distribution are normal and homogeneous. The data was analyzed by Paired Sample TTest. The result of analysis showed that wife was expect bigger than husband on openness strategy and advice strategy. There's no difference perspective between husband and wife for other strategies.
\end{abstract}

Keywords - M arital, Husband, Wife, Businessman.

\section{INTRODUCTION}

Marriage relationship is one factor for male entrepreneurs to be successful in running their business. Entrepreneur can be associated with work under high pressure and uncertain circumstances [1]. The previous study found that spousal involvement has a strong positive correlation to business efficacy for male entrepreneurs. In addition, the social support of couples is also positively correlated to the business efficacy of male entrepreneurs. Also disclosed in previous research that the wife will be involved and support the husband's business when the husband seeks to improve the relationship marriage by performing certain strategies and actions [2].

Limitations in previous studies are only seen from the point of view of the husband, where the previous findings are when the husband has made certain strategies to maintain the relationship, then the wife will be involved and support the business of the husband [2]. On the other hand, Bell reveals that precisely the most important is how the wife perceives the strategy that has been done by her husband, where this will impact on the marital satisfaction of the wife [3]. Equity theory considers that everyone will provide a subjective assessment

Ersa Lanang Sanjaya Lecturer, School of Psychology, Ciputra University, Surabaya, Indonesia

Jimmy Ellya Kurniawan Associate Professor, School of Psychology, Ciputra University, Surabaya, Indonesia of their relationship with their partner. This assessment comes from how individuals compare their expectations to the reality that they get from their partners. If the expectation was fulfilled by the spouse, it will be a reward. The other way, if the expectation wasn't fulfilled by the spouse, it will be a cost. If the cost is higher than the reward then the individual will feel under benefit and that's not good for the relationship [4].

Wife's expectation of husband's effort in maintaining marital relationships should be comparable to the attitude and efforts of the husband in trying to maintain their marital relationship. In looking at the relationship of husband and wife, it is not enough just to see what the husband has done in strategy of maintaining marital relationship toward his wife, but it is also necessary to see how the similarity between the expectation of the wife and the efforts made by the husband.

The marital relationship strategies in this research used six dimensions, namely openness (open to discuss things with their spouse), assurance (showing commitment to spouse about future), positivity (bring positive and pleasant atmosphere), conflict management (keeping relationship with patient and forgiving spouse), social networks (having the same community between spouse), and advice (giving opinions and feedback to spouse when experiencing problems) [3][5]. In this study, researchers did not see the behavior in the application of relationships strategy, but more to the attitude of the husband and wife's expectations related to the implementation of relationship strategy to maintain the relationship of marriage. The purpose of this study was to compare the attitudes of husband's strategy to maintain the relationship and the wife's expectations related to the husband's behavior to maintain the marital relationship, where there should be no difference between the husband's attitudes with wife's expectation.

Hypothesis:

1. There is no difference between the husband's attitude with the wife's expectation of the marital relation strategy on the assurance dimension.

2. There is no difference between the husband's attitude with the wife's expectations of the marital relation strategy on the dimensions of openness.

3. There is no difference between the husband's attitude with the wife's expectation of the marital relation strategy on the dimension of conflict management.

4. There is no difference between the husband's attitude with the wife's expectation of the marital relation strategy on positivity dimension. 
5. There is no difference between the husband's attitude with the wife's expectation of the marital relation strategy on the advice dimension.

There is no difference between the husband's attitude with the wife's expectation of the marital relation strategy on the social network dimension

\section{METHOD}

\section{A. Participant}

The population in this study are married couples whose husbands work as entrepreneurs who are living in Surabaya. The number of subjects in this study were 14 married couples. The subject age of this study between $27-53$ years old. Their marital duration between $1-25$ years old. Sampling technique used was purposive sampling.

\section{B. Research Tool and Procedure}

This research used modification of marital relation strategies scale by Kurniawan \& Sanjaya [2]. That scale was constructed based on dimensions by Stafford \& Canary and Stafford, Dainton, \& Haas [3][5]. Basically the scale for husband and wife uses the same pattern and basic dimensions, but the researchers were modified by changing the object of the statement item and the response answer. Example of the item for the husband is "I need to show my loyalty commitment to the wife" while for wife the item of the statement is modified to "My husband demonstrates his loyalty commitment to me". For husbands using Likert Scale with 5 choices of answers where score $1=$ very unimportant, up to score $5=$ very important. For the wife using Likert Scale with 5 choices answer where score $1=$ very not expected, up to score $5=$ very expected. In addition, the reliability for the whole dimension of both the husband and wife side has quite good because it has a value of $\alpha>0.75$

TABLE I

RELIABILITY

\begin{tabular}{llll}
\hline Dimension & $\begin{array}{l}\text { Total } \\
\text { Item }\end{array}$ & Husband & Wife \\
\hline Assurance & 3 & 0.866 & 0.776 \\
Openness & 3 & 0.759 & 0.929 \\
Conflict & 2 & 0.842 & 0.846 \\
$\begin{array}{l}\text { Management } \\
\text { Positivity }\end{array}$ & 3 & 0.952 & 0.892 \\
& & & \\
Advice & 3 & 0.859 & 0.905 \\
Social Network & 3 & 0.798 & 0.799 \\
& 17 & & \\
\hline
\end{tabular}

\section{RESULT}

All of marital relation strategies have normal distribution, that indicated by the significance value Kolmogorov-Smirnov p> 0.05. Homogeneity test shows that the dimensions of Assurance, Openness, Positivity, and Advice are homogeneous with Levene Test significance $p>0.05$. While the dimensions of Conflict Management and Social Network is not homogeneous with Levene Test significance value of $p$ $<0.05$

TABLE II

DATA DISTRIBUTION

\begin{tabular}{|c|c|c|c|}
\hline $\begin{array}{l}\text { Strategies } \\
\text { Distribution }\end{array}$ & $\begin{array}{l}\text { Kolmogorov- } \\
\text { Smirnov-Z }\end{array}$ & $\mathbf{P}$ & Remark \\
\hline Assurance & 1.251 & 0.087 & $\begin{array}{l}\mathrm{p}>0.05= \\
\text { Normal }\end{array}$ \\
\hline Openness & 1.035 & 0.235 & $\begin{array}{l}\mathrm{p}>0.05= \\
\text { Normal }\end{array}$ \\
\hline $\begin{array}{l}\text { Conflict } \\
\text { Management }\end{array}$ & 1.044 & 0.226 & $\begin{array}{l}\mathrm{p}>0.05= \\
\text { Normal }\end{array}$ \\
\hline Positivity & 1.252 & 0.087 & $\begin{array}{l}\mathrm{p}>0.05= \\
\text { Normal }\end{array}$ \\
\hline Advice & 0.902 & 0.389 & $\begin{array}{l}\mathrm{p}>0.05= \\
\text { Normal }\end{array}$ \\
\hline $\begin{array}{l}\text { Social } \\
\text { Network }\end{array}$ & 0.615 & 0.844 & $\begin{array}{l}\mathrm{p}>0.05= \\
\text { Normal }\end{array}$ \\
\hline
\end{tabular}

*) p (sign, 2 tailed $)$

T ABLE III HOMOGENITY TEST

\begin{tabular}{llll}
\hline $\begin{array}{l}\text { Strategies } \\
\text { Distribution }\end{array}$ & $\begin{array}{l}\text { Levene } \\
\text { Statistic }\end{array}$ & $\begin{array}{l}\mathbf{p} \\
\text { (sign) }\end{array}$ & Remark \\
\hline Assurance & 0.010 & 0.921 & Equal Variances \\
Openness & 3.684 & 0.066 & Equal Variances \\
Conflict & 6.259 & 0.019 & Unequal Variances \\
Management & & & \\
$\begin{array}{l}\text { Positivity } \\
\text { Advice }\end{array}$ & 0.332 & 0.569 & Equal Variances \\
Social Network & 0.734 & 0.399 & Equal Variances \\
\hline
\end{tabular}

Based on the result of T-Test analysis showed that there is no significant difference between husband's attitude with wife expectation on assurance, conflict management, positivity, and social network dimension with significance $p>0.05$. While there is a significant difference between husband's attitude with wife expectation on openness and advice dimension, with a significance value of $p<0.05$. From this result the hypotheses 1 , hypothesis 3, hypothesis 4 and hypothesis 6 are accepted, whereas hypothesis 2 and hypothesis 5 are rejected. Another interesting point is found in this study, although not all hypotheses are accepted but in all dimensions of the strategy of maintaining marital relationships, the wife always has a higher average score than the husband. 
TABLE IV

INDEPENDENT SAMPLE T-TEST BETWEEN HUSBAND ATTITUDE AND WIFE EXPECT ATION

\begin{tabular}{lllccl}
\hline Strategies & Husband Mean & Wife Mean & T & P & Remark \\
\hline Assurance & 13.143 & 13.571 & -0.575 & 0.570 & $\mathrm{p}>0.05=$ similar \\
Openness & 12.143 & 14.143 & -3.286 & 0.003 & $\mathrm{p}<0.05=$ difference \\
Conflict Management & 8.786 & 8.929 & -0.356 & 0.726 & $\mathrm{p}>0.05=$ similar \\
Positivity & 13.000 & 13.143 & -0.171 & 0.866 & $\mathrm{p}>0.05=$ similar \\
Advice & 11.357 & 13.571 & -3.173 & 0.004 & $\mathrm{p}<0.05=$ difference \\
Social Network & 11.429 & 12.000 & -0.718 & 0.482 & $\mathrm{p}>0.05=$ similar \\
\hline
\end{tabular}

*) p (sign, 2-tailed)

\section{DISCUSSION}

The results of this study indicate that there is no difference between the attitudes of husband's effort to do marital relationship strategy and wife's expectation toward husband in assurance, conflict management, positivity and social network dimension, whereas there is significant difference in openness and advice dimension. Another interesting thing, on the whole dimension, the mean of the husband is always lower than the wife, meaning the wife has high expectations but not with the husband's attitude.

Several dimensions are consistent with Stafford \& Canary research [5]. Assurance dimensions show marriage provides a sense of security to couples for long-term relationships so that couples have the possibility to have and share common goals. Weddings make couples have less time to interact with an individual's social network, therefore creating the same social network among them, besides because most of the time has been spent together, husband and wife usually have no energy to build an individual social network. The findings of Stafford \& Canary [5] also reveal that husbands often create an atmosphere of being positive in their marital relationships as a strategy in establishing marital relationships so that this is in line with the expectations of the wife. In addition, findings from Fincham, Davila, and Beach [6] men has better conflict resolution capabilities than women, because men are wiser and rational than women. This makes the strategy pursued by the husband in accordance with the expectation of the wife.

In this study, it was found that there were significant differences in the dimension of openness in the husband's attitude related to the effort of marriage relationship strategy compared with the wife's expectation related to husband's effort. Wives are more expecting a more open husband, while the husband feels openness is not a strategy to establish important marital relationships. If associated with Hofstede, Hofstede, and Minkov [7] findings, Indonesia is a country with high power distance, ranked 15th among 76 countries. Countries with high power distance always put the status as important, where in the status of having certain rights and obligations that are usually more profitable individuals with higher status. In addition, the subject of this study is the entrepreneur husband that have their own business, where the husband has more power than the wife. Thus for countries with high power distance, individuals who have lower power, in this case the wife, must obey the husband who has more power than she, so the husband feels no need for full openness to his wife.

In addition, there are differences in husband's attitude and wife's expectations in the advice dimension in marital relationship strategies. Stafford, Dainton, \& Haas [3] revealed that advice is a strategy usually performed by someone who has high masculinity. Masculinity has a tendency to problem solving, and advice is a form of assertive behavior with the aim of doing problem solving. Hofstede, Hofstede, and Minkov [7] research revealed that Indonesian index masculinity is ranked 42 out of 76 countries, or tend to be a feminism. This assumed that the strategy of establishing the relationship dimension of advice is not very work in Indonesian Culture.

Another interesting finding is that husband's mean value of the six strategies of marriage relationships is always lower than wife. This means that the wife's expectations related to the husband's efforts to establish marriage relationships are always higher than the husband's attitude to seek it. This is because women are more concerned about their relationships. In addition women have more initiative to discuss the problems related to her husband. [8]. Instead of men tend to withdraw and tend to ignore the problems that occur in the relationship of husband and wife [9]. This is what causes women to have more expectations related to the husband's strategy efforts to establish marital relationships compared with his own husband's attitude to do so. Kitson reveals often the divorced man is unaware of why the divorce happen [10].

Dissatisfaction in marriages leading to conflicts in marital relationships often arises because of differences in unfinished expectations [11]. Amato reveals that dissatisfaction in marriage is a major cause of divorce [12][13]. The lack of love in the home can also be the cause of bad marital relations [14]. In its problem, dissatisfaction in marriage often arises unconsciously from beginning. Therefore, based on the findings of this study, it is expected that communication between husband and wife is further enhanced so that the wife's expectations and efforts of the husband can be aligned, especially in openness and advice strategies. Husband has to improve his gender equity concept to more open with his wife. Husband has to increase his assertiveness skill as well to be more comfort in giving advice to his spouse.

\section{ACKNOWLEDGMENT}

We acknowledge the support and generosity of Kemenristek Dikti Republic of Indonesia that supported with 
Penelitian Hibah Bersaing (PHB) / Penelitian Produk Terapan (PPT) 2017 for this research.

\section{REFERENCES}

[1] Hmieleski, K. M., \& Baron, R. A. (2008). When does entrepreneurial efikasi enhance versus reduce firm performance? Strategic Entrepreneurship Journal , 57-72.

[2] Kurniawan, J. E., \& Sanjaya, E. L. (2016). The role of marital relation strategies in business efficacy of young male entrepreneurs with spousal involvement and support as mediators. Open Journal of Social Sciences , 4, 56-66.

[3] Stafford, L., Dainton, M., \& Haas, S. (2000). Measuring routine and strategic relational maintanance: scale revision, sex versus gender roles, and the predicton of relational characteristic. Communication Monograph , 306-323.

[4] Stafford, L., \& Canary, D. J. (2006). Equity and interdependance as predictors of relational maintenance strategies. The Journal of Family Communication , 6(4), 227-254.

[5] Stafford, L., \& Canary, D. J. (1991). Maintanance strategic and romantic relationship type, gender and relational characteristics. Journal of Social and Personal Relationship , 217-242.

[6] Fincham, F. D., Davila, J., \& Beach, S. R. (2004). Forgiveness and conflict resolution in marriage. Journal of Family Psychology, Vol 18, No 1, 72-81.

[7] Hofstede, G., Hofstede, G. J., \& Minkov, M. (2010). Culture and organization software of the mind : Intercultural cooperation and its importance for survival. New York: Mc Graw Hill.

[8] Thompson, L., \& Walker, A. J. (1991). Gender in families: Women and men in marriage,

work, and parenthood. In A. Booth (Ed.), Contemporary families: Looking forward,

looking back (pp. 76-102). Minneapolis, MN: National Council on Family Relations

[9] Gottman, J. M. (1994). What predicts divorce? Hillsdale, NJ: Lawrence Erlbaum.

[10] Kitson, G. C., Babri, K. B., \& Roach, M. J. (1985). Who divorces and why: A review. Journal of Family Issues, 6, 255-293

[11] Luna, M. E., \& Zepeda, H. R. (2013). Areas of conflict in the intimate couple. Trames , 1, 87-100 DOI: 10.3176/tr.2013.1.04.

[12] Amato, P. R. (2000). The consequences of divorce for adults and children. Journal of Marriage \& the Family, 62, 1269-1287

[13] Amato, P. R., \& Preveti, D. (2003). People's reason for divorcing: gender, social class, the life course, and adjusment. Journal of Family Issues, Vol 24 no 5, 602-626.

[14] Levinger, G. (1966). Sources of marital dissatisfaction among applicants for divorce. American Journal of Orthopsychiatry, 36, 803-807

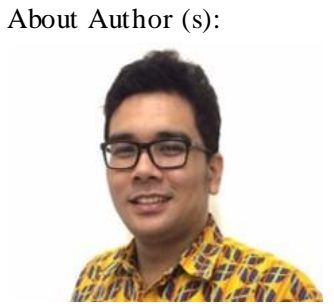

Ersa Lanang Sanjaya was born in Indonesia in 1988. He is received his Master Degree of Psychology from Universitas Airlangga in 2013. He is lecturer with interest research area in psychology and marital relation.

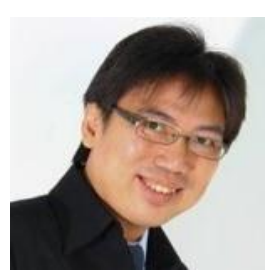

Jimmy Elya Kurniawan was born in Indonesia in 1973. He is received his Doctoral Degree of Psychology from Universitas Airlangga in 2015. He is an Associate Professor with interest research area in psychology and entrepreneurship 